\title{
Pharmaceuticals and pesticides in urban groundwater: a case study - Maribor, Slovenia
}

\author{
A. Koroša \& N. Mali \\ Geological Survey of Slovenia, Slovenia
}

\begin{abstract}
Pharmaceuticals and pesticides are pollutants belonging to the emerging organic compounds (EOC). EOC in groundwater can cause adverse effects on the environment and human health. They enter the natural environment as a result of various activities, their presence in groundwater being a result of the current anthropogenic activities and pollution loads from the past. The paper reviews the occurrence, the contamination level and sources of selected contaminants in aquifer Vrbanski plato, which is the main water resource for the city of Maribor and the surrounding municipalities. 54 groundwater and 4 surface water samples were collected in the region of Maribor, four times in different hydrogeological periods, and a total of 12 selected contaminants were analyzed in this study. Carbamazepine, propyphenazone and caffeine were determined as indicators of urban pollution, while pesticides and their metabolites (atrazine, desethylatrazine, deisopropylatrazine, terbuthylazine, desethylterbuthylazine, metolachlor, simazine and propazine, diuron) were defined as indicators of mainly agricultural pollution. The most frequently detected pollutants were atrazine, desethylatrazine, carbamazepine, desethylterbuthylazine and simazine, whereas diuron and propyphenazone were the least frequently detected. Detection frequencies of pharmaceuticals (carbamazepine, propyphenazone and caffeine) were lower than detection frequencies of pesticides. Atrazine $(228.84 \mathrm{ng} / \mathrm{l})$ and desethylatrazine (102.98 ng/l) showed the highest concentrations. All the selected EOCs were detected and present in the aquifer underlying the city of Maribor.
\end{abstract}

Keywords: pharmaceuticals, pesticides, groundwater, pollution, urban groundwater, Slovenia. 


\section{Introduction}

Pharmaceuticals and pesticides belong to a group of pollutants the impact of which on the environment and consequently on human health is not fully known. They are found in the mud of sewage treatment plants, surface waters, groundwater and even drinking water. The emerging organic compounds (EOCs) enter the groundwater as a result of various anthropogenic activities: from urban and agricultural environment (leaching from municipal and industrial wastewater treatment plants, leaking from sewage systems, through the use of fertilizers on agricultural land, municipal wastes, etc.).

Most of these substances enter the environment, with no preliminary studies of their effects on humans and animals having been made. Over the last few years, much intensive researches on the impact of the urban and agricultural activities on groundwater have been made worldwide. Its focus varied from a detection quality of groundwater to the understanding the migration process and decomposition of pollutants through the aquifer.

The objective of this study was to investigate and determine the presence of selected emerging contaminants and their concentrations in aquifer Vrbanski plato.

\section{Study area}

The city of Maribor (Figure 1) is located in the northeastern part of Slovenia and is the second largest city in Slovenia. The Maribor area has a moderate continental climate with a mean annual temperature between 8 and $10^{\circ} \mathrm{C}$ and a typical continental precipitation regime. The average yearly rainfall in the area lies between 1100 and $1200 \mathrm{~mm}$. In 2010 and 2011, the average monthly rainfall varied from minimum $1.6 \mathrm{~mm}$ in February 2011 to maximum $174.6 \mathrm{~mm}$ in September 2010 .

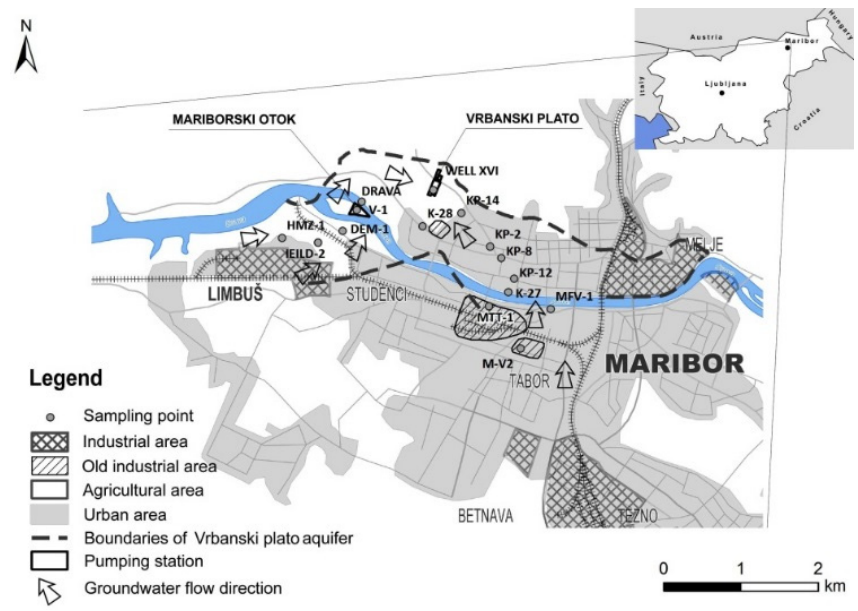

Figure 1: Study area and sampling point locations. 
The study area (Figure 1) comprises the aquifer Vrbanski plato, which is the main water resource for Maribor and its surrounding municipalities. The city of Maribor is situated on the banks of the river with an average discharge of $30 \mathrm{~m}^{3} / \mathrm{s}$. The aquifer below the city, Vrbanski plato, is part of the large Drava field aquifer system which extends south from the city and represents one of the biggest aquifer systems in the country. Water from the aquifer Vrbanski plato is pumped at two locations; at the pumping station "Vrbanski plato" (400-500 1/s) and at the pumping station "Mariborski otok" (around $150 \mathrm{l} / \mathrm{s}$ ) (Figure 1). The axis of the Vrbanski plato aquifer runs from the Drava river banks to Limbuš, across Mariborski otok, to the Vrbanski plato groundwater pumping station. In this part, it rotates towards the south, under the Drava River, towards Tabor and forward to the Drava field (Figure 1). The basement of the city is represented by a big Quaternary alluvial open aquifer of high permeability with a thickness of 20 to 40 $\mathrm{m}$. The general direction of groundwater flow is from west to east (Figure 1). The thickness of the saturated zone is estimated at 7 to 13 meters [1]. Based on previous research, the hydraulic conductivity of the gravel is estimated at around $5 \times 10^{-3}$ to $2 \times 10^{-2} \mathrm{~m} / \mathrm{s}[1]$.

\section{Selected contaminants}

A total of 12 contaminants and their metabolites that can occur in groundwater were analyzed in this study. They were selected based on their occurrence in groundwater and the environment, on knowledge of how they transform, and on the availability of standards and analytical methods. Carbamazepine, propyphenazone and caffeine are representative of the urban activities (sewage network) [2]. Indicators of mainly agricultural contaminants are pesticides: atrazine, desethylatrazine, deisopropylatrazine, terbuthylazine, desethylterbuthylazine, metolachlor, simazine, propazine and diurun [2].

Sources of pharmaceuticals in groundwater include septic tanks, urban sewer system leakage and wastewater treatment discharge in surface water and groundwater [3]. Carbamazepine is a drug that has been used for almost fifty years in the treatment of epilepsy, mood disorders, and as an analgesic, in particular for the treatment of chronic diseases. Studies confirmed that carbamazepine is not noticeably degradable, has little or no sorption in the water-sediment system and is highly resistant to biodegradation. It is also resistant to hydrolysis and highly persistent in groundwater [4]. Propyphenazone is an active substance in drugs acting on the nervous system and is classified as an analgesic. It is used in combination with paracetamol and caffeine relieving pain and fever [5]. It is much more persistent than caffeine, yet less than carbamazepine. Caffeine is one of the world's most commonly used stimulants. It is present in many drinks and also used for therapeutic purposes. Its half-life time is from 24 hours [6] and, according to some sources, even up to 12 days [7]. Therefore it can be considered an indicator of fast transport and nearby source. It is less persistent in groundwater than in surface water $[2,8]$.

Pesticides are substances mainly used in agriculture, however, they are also found in households and industry, used for the control of pests, weeds or plant 
diseases [2]. They are also used in forestry, wood industry, shipbuilding, etc. Even the pesticides which have been banned since 2004, like atrazine and simazine, can still occur in groundwater [16, 17]. By their nature pesticides are biologically active, and some of them are even toxic. In groundwater they occur as primary compounds and as their metabolites. The concentrations of metabolites and degradation products in groundwater were in some research shown to be higher compared to those of their parent compound [9, 10]. They often enter the environment through their use in agriculture; they enter through cultivated areas into the unsaturated zone to groundwater and finally to the user [2].

\section{Sampling and analytical methods}

The sampling area extends from Limbuš, over the whole area of the aquifer Vrbanski plato to the passage of field Dravsko polje. Since no data on current EOC levels are available for this region a sampling network was set up on the entire aquifer, with a higher density of sampling points in the urban area, where increased levels of substances in groundwater were expected.

Sampling of groundwater and the Drava River was conducted from May 2010 to October 2011. Groundwater samples were taken from boreholes in filter areas at fourteen sampling sites, four times in different hydro-geological periods, which is 60 samples collected all together with samples from Drava River.

Chemical analyses of samples for organic contaminants were carried out in the laboratory of JP Vodovod-Kanalizacija. A modification of the EPA 525.2 method, which is based on solid phase extraction (SPE) and the use of gas chromatography with mass spectrometry (GC-MS), was used to determine the concentration of contaminants. A more detailed description of this method is given by Auersperger et al. [11].

For statistical analyses values below the limit of detection were replaced by LOD/2 [12]. The substitution method with LOD/2 is also used in Slovenia in statistical calculations for water quality reports in Decree in groundwater status [13]. Data processing and calculations were performed by the software Statistica [14].

\section{Results}

Most often detected concentrations in Vrbanski plato aquifer (above LOD) were carbamazepine, atrazine, desethylatrazine, desethylterbuthylazine and simazine. Least frequently detected were diurun, propyphenazone and deisopropylatrazine (Table 1). None of the groundwater samples contained all the selected EOCs in one sampling and all compounds were present in all samples. Detection frequencies of pharmaceuticals (carbamazepine, propyphenazone and caffeine) above LOD were lower than those of pesticides. Carbamazepine was detected in $80 \%$, caffeine in $50 \%$ and propyphenazone in $16.7 \%$ of samples. In the group of pesticides the most frequently detected were atrazine (in 91.7\%) and desethylatrazine (in 96.7\%). Terbuthylazine was detected in 56.7\%, 
desethylterbuthylazine in $71.7 \%$, metolachlor in $36.7 \%$, deisopropylatrazine in $16.7 \%$, siamazine in $71.7 \%$ and propazine in $38.4 \%$.

Table 1: Target pollutants, their limits of detection, number of detected concentration, min and max values (ng/l) and their average concentrations.

\begin{tabular}{|c|c|c|c|c|c|}
\hline & Limit of detection & $\begin{array}{c}\text { Number of } \\
\text { samples above the } \\
\text { detection limit }\end{array}$ & Min. (ng/I) & Max. (ng/I) & $\begin{array}{l}\text { The average } \\
\text { value (ng/l) }\end{array}$ \\
\hline Carbamazepine & $<\mathrm{LOD}=10<\mathrm{LOQ}=33.3$ & 48 & 10,02 & 87,98 & 26,48 \\
\hline Propyphenazone & $<\mathrm{LOD}=2.0<\mathrm{LOQ}=6.7$ & 11 & 2,02 & 10,66 & 3,55 \\
\hline Caffeine & $<\mathrm{LOD}=2.0<\mathrm{LOQ}=6.7$ & 31 & 2,24 & 108,38 & 13,05 \\
\hline Atrazine & $<\mathrm{LOD}=2.0<\mathrm{LOQ}=6.7$ & 56 & 2,03 & 228,84 & 57,17 \\
\hline Desethylatrazine & $<\mathrm{LOD}=2.0<\mathrm{LOQ}=6.7$ & 59 & 2,30 & 102,98 & 43,83 \\
\hline Deisopropylatrazine & $<\mathrm{LOD}=10<\mathrm{LOQ}=33.3$ & 10 & 10,06 & 20,35 & 16,27 \\
\hline Terbuthylazine & $<\mathrm{LOD}=1.0<\mathrm{LOQ}=3.3$ & 34 & 1,00 & 25,73 & 2,37 \\
\hline Desethylterbuthylazine & $<\mathrm{LOD}=2.0<\mathrm{LOQ}=6.7$ & 43 & 2,06 & 6,98 & 3,29 \\
\hline Simazine & $<\mathrm{LOD}=2.0<\mathrm{LOQ}=6.7$ & 44 & 2,73 & 29,60 & 9,51 \\
\hline Metolachlor & $<\mathrm{LOD}=2.0<\mathrm{LOQ}=6.7$ & 22 & 2,05 & 67,61 & 11,60 \\
\hline Propazine & $<\mathrm{LOD}=2.0<\mathrm{LOQ}=6.7$ & 23 & 2,05 & 4,08 & 2,84 \\
\hline Diurun/linuron & $<\mathrm{LOD}=2.0<\mathrm{LOQ}=6.7$ & 7 & 3,76 & 8,00 & 6,01 \\
\hline
\end{tabular}

In the pharmaceutical group, caffeine showed the highest concentrations (Table 1), which were measured in the Drava River (up to $108.38 \mathrm{ng} / \mathrm{l}$ ). The highest concentrations of carbamazepine are up to $87.98 \mathrm{ng} / \mathrm{l}$ and of propyphenazone up to $10.66 \mathrm{ng} / \mathrm{l}$. Among pesticides, atrazine (up to $228.84 \mathrm{ng} / \mathrm{l}$ ) and desethylatrazine (up to $102.98 \mathrm{ng} / \mathrm{l}$ ) have the highest concentrations. High concentrations were also those of metolachlor (up to $67.61 \mathrm{ng} / \mathrm{l}$ ), followed by the concentrations of simazine (up to $29.60 \mathrm{ng} / \mathrm{l}$ ), terbuthylazine (up to $25.73 \mathrm{ng} / \mathrm{l}$ ), deisopropylatrazine (up to $20.35 \mathrm{ng} / \mathrm{l}$ ), diurun (up to $8.00 \mathrm{ng} / \mathrm{l}$ ), desethylterbuthylazine (up to $6.98 \mathrm{ng} / \mathrm{l}$ ) and propazine with the lowest concentrations (up to $4.08 \mathrm{ng} / \mathrm{l}$ ).

Concentrations of carbamazepine (Figure 2(a)) in our study varied from 10.04 ng/l in MFV-1 to $87.98 \mathrm{ng} / \mathrm{l}$ in DEM-1. Groundwater analysis shows that the maximum concentrations of carbamazepine are in piezometers on the Limbuš area (up to $87.9 \mathrm{ng} / \mathrm{l}$ - IELD-2, DEM-1) and on the area of Tabor (MTT-1 and MV-2). Settlements in the Limbuš area were in the past not connected to a sewage system. In the city centre area (KP-14, KP-25, KP-8, KP-27), which is in the recharge area of the Vrbanski plato pumping station, carbamazepine concentrations of up to 20 $\mathrm{ng} / \mathrm{l}$ were measured. In the Tabor area, which is considered a wider catchment area of wells on Vrbanski plato, carbamazepine concentrations reach values up to 60 $\mathrm{ng} / \mathrm{l}$.

Concentrations of propyphenazone (Figure 2(b)) were measured above LOD at 7 sampling points. The highest concentrations were measured in the city centre at the sampling points KP-14 (10.66 ng/l), MFV-1 (2.29 ng/l), K-27 (2.61 ng/l) and Well XVI (4.96 ng/l). The highest concentration was observed at sampling point KP-14 (10.66 ng/l). Propyphenazone originates from the city centre, compared with the area of Limbuš (Figure 2(b)). 

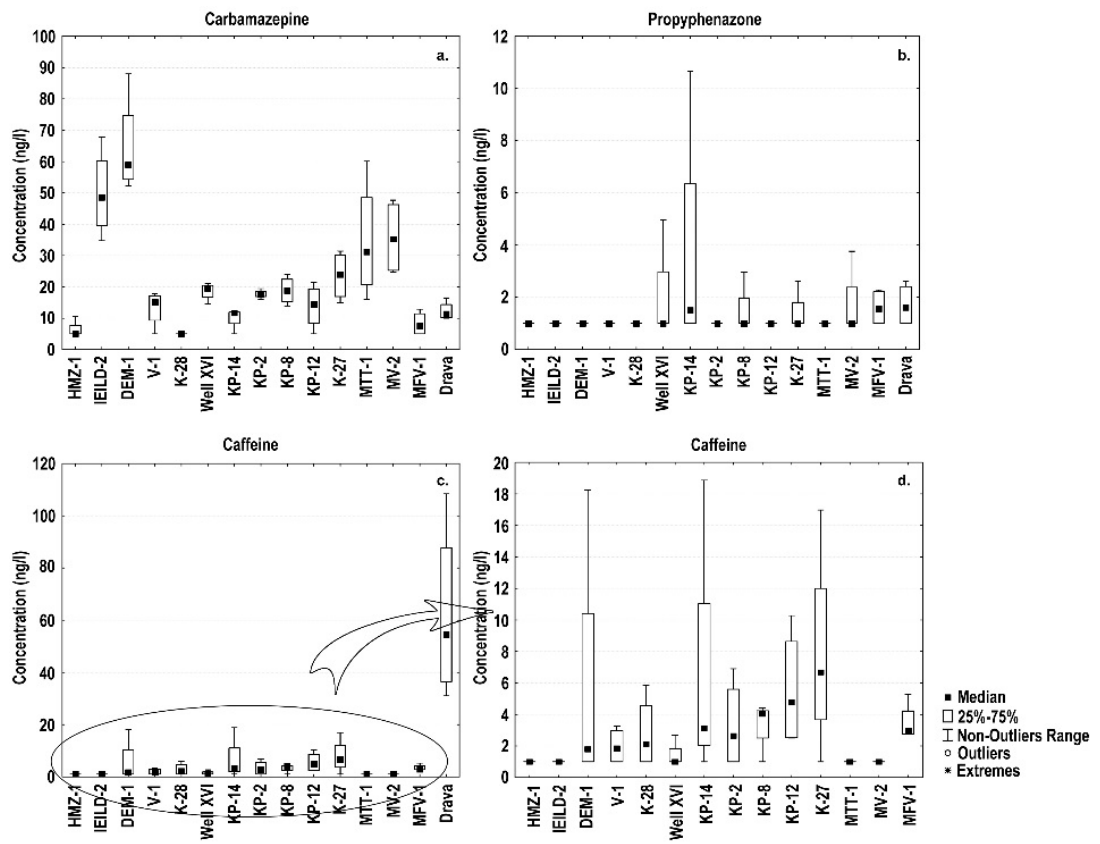

Figure 2: Detected concentrations of pharmaceuticals in aquifer Vrbanski plato.

Maximum concentrations of caffeine (Figure 2(c)) ranged between $31.03 \mathrm{ng} / \mathrm{l}$ and $108.38 \mathrm{ng} / \mathrm{l}$ and were detected in the Drava River, as expected $[3,10]$. The maximum concentration of caffeine in groundwater (Figure 2(d)) was detected at sampling point DEM-1 and its value was $18.8 \mathrm{ng} / \mathrm{l}$. Throughout the city centre concentrations of caffeine were set above LOD. At sampling points MV-2, MTT1, IELD-2 and HMZ-1, all concentrations in all 4 sampling periods were under LOD.

Although the use of atrazine is forbidden, atrazine and its metabolite desethylatrazine still occur at all sampling points. The concentrations of both, atrazine and desethylatrazine (Figure 3), are higher at the sampling points KP-2, MV-2, IEILD-2, DEM-1, MTT-1, etc. The other metabolite, deisopropylatrazine (Figure 3(c)), is represented at the highest level in the Limbuš area at IEILD-2 (from 13.06 to $20.10 \mathrm{ng} / \mathrm{l}$ ) and DEM-1 (from 20.13 to $20.35 \mathrm{ng} / \mathrm{l}$ ). At some points in the urban area, the highest values of atrazine and desthylatrazine, were beyond the limits determined by the Drinking Water Regulations (up to $228 \mathrm{ng} / \mathrm{l}$ in KP-2) [15]. This concentration indicates the use of pesticides in the surrounding gardens (Figure 3).

Concentrations of terbuthylazine (Figure 4(a)) are lower compared to the concentrations of its metabolite desethylterbuthylazine (Figure 4(b)). The highest concentration of terbuthylazine occurred at sampling point KP-14 (up to 25.73 ng/l). Simazine (Figure 5(a)) showed the highest concentrations in groundwater at the sampling points in the Limbuš area in IEILD-2 (up to $28.61 \mathrm{ng} / \mathrm{l}$ ) and DEM-1 

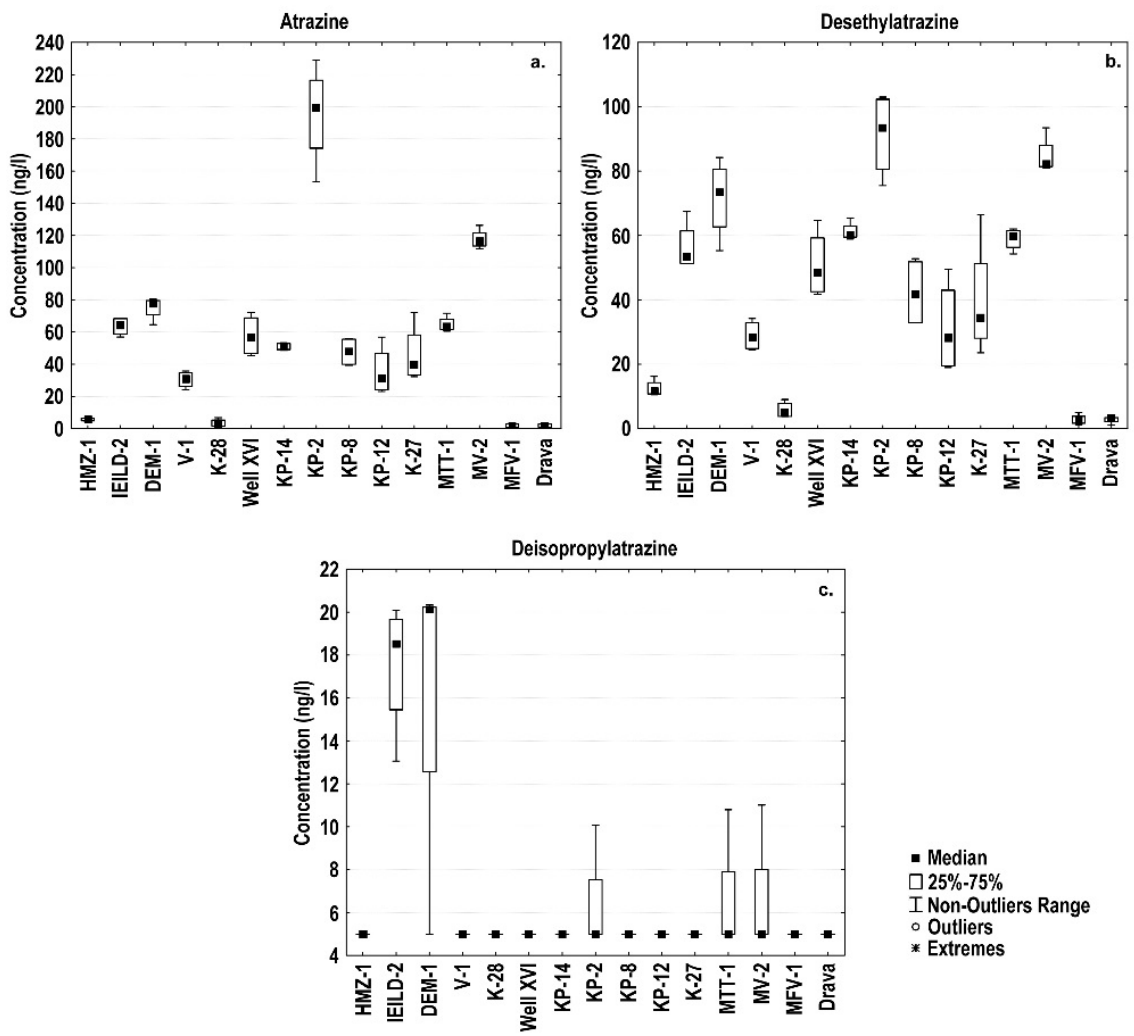

Figure 3: Detected concentrations of atrazine and its metabolites in aquifer Vrbanski plato.
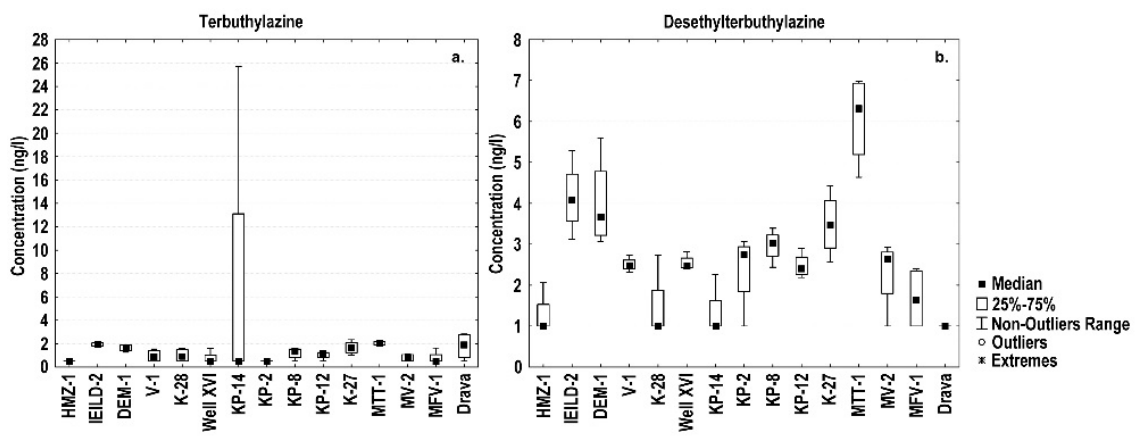

Figure 4: Detected concentrations of therbuthylazine and desethylterbuthylazine in aquifer Vrbanski plato. 

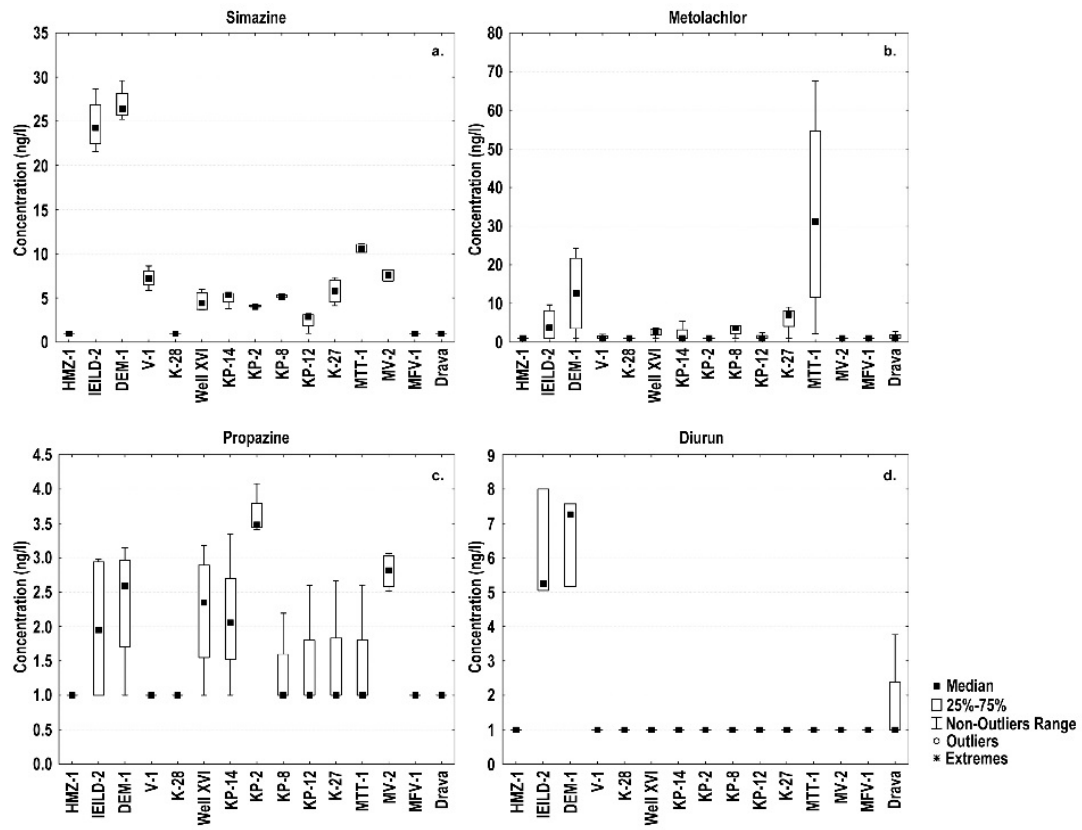

Figure 5: Detected concentrations of simazine, metolochlor, propazine and diurun in aquifer Vrbanski plato.

(up to $29.60 \mathrm{ng} / \mathrm{l}$ ). Throughout the whole research period, metolachlor (Figure 5) concentrations were highest at the sampling point MTT-1, which indicates a point contamination in the former industrial MTT area (Figure 1). The concentrations of propazine were low at all sampling points (up to $4.08 \mathrm{ng} / \mathrm{l}$ ) (Figure 5(c)).

Fram and Belitz [4] reported that some of the detected pesticides can suggest urban rather than agricultural sources. A well-known herbicide for urban use is diuron, which has in our case been detected only at the sampling points DEM-1 (7.57 ng/l), IEILD-2 (8.00 ng/l) and in the Drava river (2.5 ng/l) (Figure 5(d)). Researchers claim that diurun is used in household products, which coincides with its possible origin in the Limbuš settlement area.

\section{Discussion}

The objective of the presented study was to investigate and determine the presence of selected emerging contaminants and their concentrations in aquifer Vrbanski plato. Obtained results show that groundwater from Vrbanski plato aquifer contains organic compounds from different sources.

Concentrations of pharmaceuticals in Maribor show that urban areas have an impact on the quality of groundwater, which has been expected. In the Limbuš area, the concentrations of carbamazepine are elevated. It is a suburban area, where in the past the sewage system was poorly regulated. Concentrations of caffeine are increased in the city center area, which coincides with the urban environment and 
sewage system. Pesticides in groundwater are a result of both agricultural and urban land use. Atrazine and desethylatrazine occur in the highest concentrations. In the case of terbuthylazine and its degradation product desethylterbuthylazine it can be confirmed that the concentrations of metabolite in groundwater are higher than the concentrations of its parent compound.

Although the use of preparations on the basis of some pesticides (atrazine, simazine) has in Europe been banned since 2004 [16, 17], their concentrations in our study indicate that they are still present in the environment and groundwater. The most affected area of groundwater contamination by pesticides is Limbuš area. The recharge area of Limbuš shows agricultural influence (Figure 1). High concentrations of atrazine and desethylatrazine (up to $80 \mathrm{ng} / \mathrm{l}$ ) were measured on this area. Terbuthylazine (up to $2.9 \mathrm{ng} / \mathrm{l}$ ) and its metabolite desethylterbuthylazine (up to $7.0 \mathrm{ng} / \mathrm{l}$ ) are also common.

Concentrations of pollutants in groundwater of Vrbanski plato aquifer indicate the urban source and agricultural activity. Our results show that all the investigated EOCs are detectable and present in the aquifer (groundwater) underlying the city of Maribor. According to the results, the biggest problem are pesticides, which are detected in highest concentrations.

Since the impact of the compounds is not known, potential risks of other pollutants present in groundwater, even in small concentrations, have be taken into account.

\section{Acknowledgements}

Research work was conducted in the scope of research program No. P1-0020 "Groundwater and Geochemistry" and $\mathrm{PhD}$ work of A. Koroša financed by the Slovenian Research Agency.

\section{References}

[1] Mali, N., Brenčič, M. \& Urbanc, J., Analiza vpliva črpanja na Vrbanskem platoju na gibanje podtalnice. Geološki zbornik, 10, pp. 38-41, 1996.

[2] Stuart, M., Lapworth, D., Crane, E. \& Hart, A., Review of risk from potential emerging contaminants in UK groundwater. Science of the Total Environment, 416, pp. 1-21, 2012.

[3] Lapworth, D. J., Baran, N., Stuart, M. E. \& Ward, R. S., Emerging organic contaminants in groundwater: A review of sources, fate and occurrence. Environmental Pollution, 163, pp. 287-303, 2012.

[4] Fram, M. S. \& Belitz, K., Occurrence and concentrations of pharmaceutical compounds in groundwater used for public drinking-water supply in California. Science of the Total Environment, 409, pp. 3409-3417, 2011.

[5] Scheytt, T., Mersmann, P., Lindstadt, R. \& Heberer, T., Determination of sorption coefficients of pharmaceutically active substances carbamazepine, diclofenac, and ibuprofen, in sandy sediments. Chemosphere, 60, pp. 245$253,2005$. 
[6] Zoeteman, B. C. J., Harmsen, K., Linders, J. B. H. J., Morra, C. F. H. \& Slooff, W., Persistent organic pollutants in river water and groundwater of the Netherlands. Chemosphere, 9, pp. 231-49, 1980.

[7] Buerge, I.J, Poiger, T., Muller, M.D. \& Buser, H.R., Caffeine, an Anthropogenic Marker for Wastewater Contamination of Surface Waters. Environmental Science \& Technology, 37(4), pp. 691-700, 2003.

[8] Auersperger, P., Lah, K. \& Kramarič Zidar, V., Določanje kofeina v podzemni vodi z uporabo ekstrakcije na trdno fazo in plinske kromatografije $\mathrm{z}$ masno spektrometrijo $=$ Determination of caffeine in groundwater by solid phase-extraction and gas cromatography mass spectrometry. Proc. of the Slovenski kemijski dnevi 2011, eds. Kravanja, Z., Brodnjak-Vončina, D. \& Bogataj, M, FKKT: Maribor, 2011.

[9] Kolpin, D. W., Schnoebelen, D. J. \& Thurman, E. M., Degradates Provide Insight to Spatial and Temporal Trends of Herbicides in Ground Water. Ground Water, 42, pp. 601-608, 2004.

[10] Lapworth, D. J. \& Gooddy, D. C., Source and persistence of pesticides in a semi-confined chalk aquifer of southeast England. Environmental Pollution, 144, pp. 1031-1044, 2006.

[11] Auersperger, P, Kus, J., Lah, K. \& Marsel, J., High precision procedure for determination of selected herbicides and their degradation products in drinking water by solid-phase extraction and gas chromatography-mass spectrometry. Journal of chromatography, 1088, pp. 234-41, 2005.

[12] Croghan, C. W. \& Egeghy, P. P., Methods of Dealing with Values Below the Limit of Detection using SAS, paper presented at the Southeastern SAS User Group, 2003.

[13] Uradni list RS., Uredba o stanju podzemnih voda $=$ Decree on groundwater status, Uradni list RS, 25, pp. 3332-3345, 2009.

[14] Stat Soft Inc., 2012. STATISTICA (Data Analysis Software System), Version 11 - Software. Stat Soft Inc.,www.statsoft.com.

[15] Uradni list RS., Pravilnik o pitni vodi = Rules on drinking water, Uradni list $R S$, 19, pp. 2155-2166, 2004.

[16] Commission of the European Communities., Commission Decision of 10 March 2004 concerning the non-inclusion of simazine in Annex I to Council Directive 91/414/EEC and the withdrawal of authorisations for plant protection products containing this active substance 2004/247/EC, Official Journal of the European Union, 247, pp. 50-52, 2004.

[17] Commission of the European Communities., Commission Decision of 10 March 2004 concerning the non-inclusion of atrazine in Annex I to Council Directive 91/414/EEC and the withdrawal of authorisations for plant protection products containing this active substance 2004/247/EC, Official Journal of the European Union, 248, pp. 53-55, 2004. 